\title{
Malignant Middle Ear Neoplasm
}

National Cancer Institute

\section{Source}

National Cancer Institute. Malignant Middle Ear Neoplasm. NCI Thesaurus. Code C4765.

A malignant neoplasm that affects the middle ear. Representative examples include adenocarcinoma and squamous cell carcinoma. 